\title{
Leucogram and serum acute phase protein concentrations in queens submitted to conventional or videolaparoscopic ovariectomy
}

\author{
[Leucograma e concentrações séricas de proteínas de fase aguda de gatas submetidas à ovariectomia \\ convencional ou por videolaparoscopia]
}

\author{
A.E. Alves, A.P.C. Ribeiro, P.A. Di Filippo, M.F. Apparicio, J.J. Fagliari, W.R.R. Vicente \\ Faculdade de Ciências Agrárias e Veterinárias - UNESP \\ Via de Acesso Prof. Paulo Donato Castellane, s/n, \\ 14884-900 - Jaboticabal, SP
}

\begin{abstract}
Thirty health queens were submitted to ovariectomy by conventional technique or by videolaparoscopy. In order to study the intensity of inflammatory response by means of acute phase protein analysis and white blood cell count, serum samples were taken before and until 144 hours after the surgical procedures. The protein concentrations that were significantly increased 24 hours after surgical procedures were: ceruloplasmin, hemopexin, haptoglobin, and $\alpha_{1}$-acid glycoprotein, 69.8\%, $103.5 \%$, $117.3 \%$, and $199.0 \%$, respectively, for conventional ovariectomy; and $22.3 \%, 46.1 \%, 79.8 \%$, and $74.6 \%$, respectively, for laparoscopic ovariectomy. Therefore, inflammatory response was more intense in queens submitted to conventional ovariectomy. Results indicate that the increase or decrease in acute phase proteins, as well as in white blood cells count, may be useful in the evaluation of inflammatory response induced by these surgical procedures.
\end{abstract}

Keywords: queen, videolaparoscopy, acute phase protein

\section{RESUMO}

Trinta gatas, saudáveis, foram submetidas à ovariectomia pela técnica convencional e por videolaparoscopia. Amostras de sangue foram obtidas com o objetivo de verificar a intensidade da resposta inflamatória por meio da análise das concentrações de proteinas de fase aguda e contagem de leucócitos antes e até 144 horas após procedimento cirúrgico. As proteínas que apresentaram aumento significativo 24 horas após a cirurgia foram: ceruloplasmina, hemopexina, haptoglobina e $\alpha_{l^{-}}$ glicoproteína ácida, 69,8\%, 103,5\%, 117,3\% e 199,0\%, respectivamente, para ovariectomia convencional, e 22,3\%, 46,1\%, 79,8\% e 74,6\%, respectivamente, para ovariectomia por videolaparoscopia. A resposta inflamatória foi mais evidente nas gatas submetidas à ovariectomia convencional. Os resultados mostram aumento e diminuição na concentração de proteínas de fase aguda e na contagem de leucócitos, podendo ser utilizados na avaliação da resposta inflamatória induzida por procedimentos cirúrgicos.

Palavras-chave: gata, videolaparoscopia, proteina de fase aguda

\section{INTRODUCTION}

Dog and cat population have been increasing excessively. Thus, the study of new techniques of sterilization is part of programs to control the population growth of these species with the purpose to increase the security of public health.
According to Brun (1999), among other factors, the conventional surgery is relatively inconvenience due to surgical traumatism with the risk of contamination and pain as consequence of visceral manipulation. Thus, minimally invasive procedures have been employed to reduce these inconveniences. It is 
estimated that videolaparoscopy propitiate less tissue trauma, risk of contamination, postoperative leukocytosis, discomfort, and pain during the postoperative period as well as reduction in post-surgical recovery (Malm et al., 2005).

Videolaparoscopic procedures can avoid or minimize physiological alterations such as leukocytosis (Bonica, 1992). Tissue injury of different causes, stress, pain, and immediate postoperative, 12 to 36 hours after surgery, can stimulate the hypothalamus-hypofisis-adrenal axis to release glycocorticoids which increase the production and migration of neutrophils (Tvdten, 1994). Acute phase proteins are blood proteins that change in concentration in animals subjected to external or internal challenge, such as infection, inflammation, surgical trauma, or stress (Murata et al., 2004).

The first stage of the inflammatory reaction includes many alterations named acute phase answer. The circulating concentrations of the acute phase proteins are related to the severity of the disorder and the area of tissue damage (Kent, 1992) and quantification of their concentration can provide diagnostic and prognostic information about the animal disorder (Murata et al., 2004; Petersen et al., 2004). The pathogenesis of the acute phase protein begins with the inflammatory sites, where cells involved in the innate immune response (macrophages and neutrophils) produce and release proinflamatory cytokines such as interleukin (IL)-1, IL-6, and tumor necrosis factor (TNF)- $\alpha$ (Paltrinieri, 2008). A little is known about the molecular pathogenesis of feline protein acute phase, but the majority of studies on protein acute phase production by feline cells have examined the response to specific virus infections (Paltrinieri, 2008).

The eletrophoresis study represents one of the most important tools to recognize blood proteins (Kaneko et al., 2008). The most used techniques in veterinary medicine have with primordial cellulose acetate band (Fagliari et al., 1983) and agarose films (Mattews, 1982), but all of them provide limited banding. The electrophoresis technique with sodium dodecil sulphate (SDSPAGE) is simple, less expensive, and is enable to visualize proteins with extremely low concentrations as well the identification of 20 to
30 proteins. Using this technique, Fagliari et al. (1997) identified 19 proteins in the serum proteinogram in equines with laminitis and Fagliari et al. (2002) studied the serum proteinogram of equine with acute abdomen.

The aim of the present study was to evaluate the results of hemogram and serum protein concentrations in queens submitted to videolaparoscopic or conventional ovariectomy.

\section{MATERIAL AND METHODS}

Thirty adult queens from different breeds, weighing between 1.2 and $3.9 \mathrm{~kg}$, with ages between 8 months and 3 years old, were used in the study. The animals were considered healthy after clinical, physical and laboratorial examinations and were kept in fasting for 6 hours of water and 12 hours of food before the surgical procedure.

The animals were randomly allotted into three groups with 10 queens each, as follow: Group 1 (G1): conventional ovariectomy; Group 2 (G2): ovariectomy by videolaparoscopy, and Group 3(G3): control group that was anaesthetized, but not subjected to surgery to evaluate the changes caused by this procedure alone. This study was submitted at Ethical Committee and Animal Welfare (FCAV-UNESP-Jaboticabal/Brazil) by protocol 016782-07.

Anesthesia was conducted using $0.2 \%$ acepromazine maleate (Acepran - Univet S/A), $0.05 \mathrm{mg} / \mathrm{kg}$ and buprenorphine chloridrate (Temgesic - Schering-Plough S/A), $0.01 \mathrm{mg} / \mathrm{kg}$ by intramuscular injection (IM), 30 minutes before induction. For induction and maintenance tiletamine, $5 \mathrm{mg} / \mathrm{kg}$, and zolazepam (Zoletil Virbac S/A), $5 \mathrm{mg} / \mathrm{kg}$, (IM) were used. After the animal was anesthetized a catheter (Intracath BD Brasil) was introduced in the jugular vein for blood sampling. During surgical procedure, the animal received intravenous fluid therapy with lactated Ringer's solution $(10 \mathrm{~mL} / \mathrm{kg} / \mathrm{h})$.

Animals of G1 were placed in dorsal recumbency. Ovariectomy was performed using conventional technique (midline incision), as recommended by Okkens et al. (1997). In G2, females were placed in dorsal recumbency ("Trendelenburg" position) for visceral displacement by gravity. The first access to abdominal cavity was done by the introduction of a Veres needle into the abdominal midline, 
$2 \mathrm{~cm}$ caudal to the umbilicus, with the purpose to create a pneumoperitonium (internal pressure from 8 and $10 \mathrm{mmHg} \mathrm{CO}_{2}$ ). The Veres needle was removed, and in the same punction, a $7 \mathrm{~mm}$ trocar was introduced so that the endoscopy (with a source of light and a microcamera) could be introduced. The second and third access to cavity were also made in the medium line, with the $5 \mathrm{~mm}$ trocar placed $1 \mathrm{~cm}$ caudal to the umbilicus (between the scar and the first punction) and the $10 \mathrm{~mm}$ trocar placed $1 \mathrm{~cm}$ cranial to the umbilicus (to allow the introduction of the handling tweezers). The ovaries were located and individually fixed with an atraumatic tweezer and then the titanium clips were placed in each ovary pedicle and uterotubal junction, with distance of approximately $2 \mathrm{~mm}$ between them. After hemostasia, the uterine tube, the cranial portion of the uterus, and the ovary pedicle were sectioned and the ovaries were removed through the trocar tube. Then, the abdominal cavity was deflated and the incisions were sutured in two layers, being first the muscles and then skin, using simple separate sutures, and 2-0 monofilament nylon.

Blood samples for serum protein concentrations were collected and placed in tubes without anticoagulant and for white blood cell counts in tubes with anticoagulant. They were obtained before the surgical procedures ( $0 \mathrm{~h}$ ) and at 12, 24, $48,72,96,120$, and 144 hours later. White blood cell counts were performed in automatic cell counter (ACT8 Coulter); blood smears were stained by means of Wright method (Jain, 1986) and used for differential counting of cells.

Serum protein concentrations were determined by means of SDS-PAGE, as recommended by
Weber and Osborn (1969). Concentrations of protein were determined by the use of computer assisted densitometry (Shimadzu CS 9301). Proteins were identified by the use of reference markers (Sigma) with molecular weights of $29.000,45.000,66.000,97.400,116.000$, and 205.000 Daltons (Da), and by comparison with eletrophoretic mobility of purified albumin, $\mathrm{IgG}$, haptoglobin, transferrin, ceruloplasmin, and $\alpha_{1^{-}}$ antitrypsin. Statistical analysis was performed using the SAS/1999, followed by the Tukey test for comparison of means.

\section{RESULTS AND DISCUSSION}

There was an increase in white blood cell count during the postoperative period when compared to the period before surgery, independently of the surgical procedure (Table 1). However, there was a significant difference among the groups. During the postoperative period, the group of queens submitted to laparoscopy presented the lower values compared to the conventional group. In this group, there was a peak followed by a decrease in white blood cell count 24 hours after surgery, while in the laparoscopy group, the same oscillation was observed 12 hours after surgery.

As there was no difference among the groups regarding the counts of basophils, eosinophils, lymphocytes, and monocytes and the values of these cells remained within normal range during the postoperative period, it was decided to present only the data for segmented neutrophils. The values obtained for segmented neutrophils followed a pattern similar to that described for total white blood cells count (Table 2).

Table 1. Means and standard deviation of leukocyte counts (x10 $3 / \mathrm{uL})$ of queens submitted to ovariectomy by conventional technique (G1) or by laparoscopy (G2) before and 12, 24, 48, 72, 96, 120, and 144 hours after surgery

\begin{tabular}{cccc}
\hline Period (hours) & G1 & G2 & Reference values* \\
\hline 0 & $11.1 \pm 2.3 \mathrm{Aa}$ & $10.1 \pm 3.8 \mathrm{Aa}$ & $9.5 \pm 2.3 \mathrm{Ab}$ \\
12 & $16.3 \pm 5.1 \mathrm{Ba}$ & $15.6 \pm 5.7 \mathrm{Ba}$ & $8.7 \pm 2.8 \mathrm{Ab}$ \\
24 & $16.9 \pm 3.9 \mathrm{Ba}$ & $13.2 \pm 6.1 \mathrm{Ba}$ & $9.1 \pm 1.9 \mathrm{Ab}$ \\
48 & $16.0 \pm 4.5 \mathrm{Ba}$ & $12.3 \pm 5.7 \mathrm{Bb}$ & $9.0 \pm 2.8 \mathrm{Ab}$ \\
72 & $16.1 \pm 5.3 \mathrm{Ba}$ & $11.0 \pm 2.4 \mathrm{Ba}$ & $8.7 \pm 3.1 \mathrm{Ab}$ \\
96 & $14.2 \pm 5.8 \mathrm{Ba}$ & $10.3 \pm 1.9 \mathrm{Ba}$ & $8.2 \pm 3.5 \mathrm{Ab}$ \\
120 & $12.6 \pm 4.1 \mathrm{Ba}$ & $9.0 \pm 1.8 \mathrm{Aa}$ & $8.5 \pm 2.6 \mathrm{Ab}$ \\
144 & $13.3 \pm 3.9 \mathrm{Ba}$ & $8.6 \pm 2.0 \mathrm{Ab}$ & $9.0 \pm 1.9 \mathrm{Ab}$ \\
\hline
\end{tabular}

Means followed by distinct capital letters in columns and lower case letters in rows are different $(\mathrm{P}<0.05)$.

*Reference values of healthy queens only submitted to the same anesthetic protocol used in groups 1 and 2 . 
Table 2. Means and standard deviations of neutrophil counts (x10 $3 / \mathrm{uL})$ of queens submitted to conventional ovariectomy $(\mathrm{G} 1)$ or laparoscopic ovariectomy $(\mathrm{G} 2)$ before and $12,24,48,72,96,120$, and 144 hours after surgery

\begin{tabular}{cccc}
\hline Period (hours) & G1 & G2 & Reference values* \\
\hline 0 & $7.95 \pm 1.2 \mathrm{Aa}$ & $6.66 \pm 7.1 \mathrm{Aa}$ & $5.44 \pm 1.4 \mathrm{Aa}$ \\
12 & $11.83 \pm 1.5 \mathrm{Ba}$ & $10.91 \pm 1.9 \mathrm{Ba}$ & $5.61 \pm 2.9 \mathrm{Ab}$ \\
24 & $10.94 \pm 1.3 \mathrm{Ba}$ & $8.80 \pm 2.2 \mathrm{Ba}$ & $6.10 \pm 7.7 \mathrm{Ab}$ \\
48 & $11.46 \pm 1.7 \mathrm{Ba}$ & $8.08 \pm 2.9 \mathrm{Ba}$ & $4.91 \pm 1.9 \mathrm{Ab}$ \\
72 & $10.32 \pm 2.1 \mathrm{Ba}$ & $7.24 \pm 2.9 \mathrm{Aa}$ & $5.15 \pm 1.5 \mathrm{Ab}$ \\
96 & $9.82 \pm 5.2 \mathrm{Ba}$ & $7.28 \pm 2.6 \mathrm{Aa}$ & $5.69 \pm 1.2 \mathrm{Ab}$ \\
120 & $7.32 \pm 1.7 \mathrm{Aa}$ & $5.28 \pm 1.9 \mathrm{Ab}$ & $4.92 \pm 1.3 \mathrm{Ab}$ \\
144 & $8.92 \pm 3.8 \mathrm{Aa}$ & $5.60 \pm 2.9 \mathrm{Ab}$ & $6.23 \pm 1.4 \mathrm{Ab}$ \\
\hline
\end{tabular}

Means followed by distinct capital letters in columns and lower case letters in rows are different $(\mathrm{P}<0.05)$ Tukey test. *Reference values of healthy queens only submitted to the same anesthetic protocol used in group 1 and 2 .

The increase in the number of leukocytes observed in the animals submitted to ovariectomy possibly occurred due to the action of cortisol released in animals under stress, pain, and immediate postoperative, situations presented in both procedures. According to Tvedten (1994), the concentrations of serum corticosteroids are proportional to the intensity and duration of stress and liberation of adrenocorticotrophic (ACTH), returning to basal concentrations within 12 to 24 hours, as observed in this study. Neutrophilia induced by corticosteroids has a reduced time and returns to normal values within 24 hours, as reported by Jain (1986). The authors consider that the trauma induced by the surgical procedures was discrete due to an increase in the number of leukocyte be directly proportional to the extent of the injury.

Theoretically, within a few minutes after an inflammatory stimulus, the leukocyte count in feline blood may triple and remain high for a long period. Nevertheless, the actual leukocyte count depends on the equilibrium between the rate of neutrophil production and tissue demand. It is possible that in case of exaggerated tissue demand, leukocytosis can be mild or characterized by the presence of circulating immature forms (Paltrinieri, 2008). In this study, a discrete left-shift was observed during the first three and four days in the postoperative period for G2 and G1, respectively; which according to Bush (1991) may be observed in situations of pain and stress. However, the increased values observed in animals submitted to conventional ovariectomy suggest that this procedure induces an inflammatory reaction greater than that caused by laparoscopy.
During the postoperative period, serum protein concentration was significantly higher in queens which underwent conventional ovariectomy compared to laparoscopic ovariectomy, with higher values observed at $0,12,24,48,72,96$, 120 , and 144 hours after the surgical procedure (Table 3). In general, the variation noticed for serum total protein was similar to that of neutrophils, suggesting that both are indicators of inflammatory response, as reported by Heindrich et al. (1990) and Gruys et al. (1994).

In this study in which SDS-PAGE was used, 29 protein bands were identified, with molecular weights ranging from 16.000 to $165.000 \mathrm{Da}$. However, data analyses indicate that the acute phase proteins that presented a significant increase were ceruloplasmin, hemopexin, haptoglobin, and $\alpha_{1}$-acid glycoprotein as showed in Table 3, according to Gruys et al. (1994).

Table 3 also shows the percentage of increase observed 24 hours after surgery for ceruloplasmin, hemopexin, haptoglobin, and $\alpha_{1}$ acid glycoprotein in the conventional group. Ceruloplasmin $(\mathrm{PM}=128.000 \mathrm{Da})$ presented the lowest percentage of increase in the laparoscopy group, with peak of $37.41 \%, 12$ hours after surgery. In the G1, ceruloplasmin was also the protein with the lowest increase (69.8\%) 24 hours after the procedure. In this group, the increases in hemopexin $(\mathrm{PM}=83.000 \mathrm{Da})$, haptoglobin $(\mathrm{PM}=47.000 \mathrm{Da})$, and $\alpha_{1}$-acid glycoprotein $(\mathrm{PM}=43.000 \mathrm{Da})$ were remarkable, with maximum values of $103.4 \%, 117.3 \%$, and $199.0 \%$, respectively. In the group of animals that underwent laparoscopy, these proteins presented a percentage of increase, with maximum values of $46.2 \%, 92.8 \%$, and $74.6 \%$, 
respectively. The highest percentage of increase verified in queens submitted to conventional ovariectomy was due to the larger area of contamination and greater inflammatory stimuli compared to queens submitted to laparoscopic ovariectomy. In both groups, the serum protein concentrations tended to decrease along the time, suggesting that hepatic synthesis needs the presence of inflammatory mediators, such as cytokines (Heindrich et al., 1990). Generally, the main function of these proteins is to contribute to body defenses during inflammation by modulating the immune system, by transporting molecules to prevent their potential loss or by protecting tissue from excessive damage generated by inflammatory mediators (Petersen et al., 2004)

Table 3. Percentage of increase in serum concentrations $(\mathrm{mg} / \mathrm{dl})$ of ceruloplasmin, hemopexin, haptoglobin, and $\alpha_{1}$-acid glycoprotein (acid glycop) after ovariectomy in queens by conventional technique or laparoscopy compared with values before surgery $(0 \mathrm{~h})$

\begin{tabular}{ccccccccc}
\hline Proteins & $0 \mathrm{~h}$ & $12 \mathrm{~h}$ & $24 \mathrm{~h}$ & $48 \mathrm{~h}$ & $72 \mathrm{~h}$ & $96 \mathrm{~h}$ & $120 \mathrm{~h}$ & $144 \mathrm{~h}$ \\
\hline Ceruloplasmin & & & & & & & & \\
G1 & $42.29 \mathrm{Aa}$ & $48.80 \mathrm{Aa}$ & $69.85 \mathrm{Ab}$ & $58.80 \mathrm{Ab}$ & $27.52 \mathrm{Aa}$ & $27.52 \mathrm{Aa}$ & $24.92 \mathrm{Aa}$ & $21.70 \mathrm{Aa}$ \\
G2 & $35.47 \mathrm{Aa}$ & $37.41 \mathrm{Ba}$ & $22.31 \mathrm{Bb}$ & $13.53 \mathrm{Bc}$ & $10.83 \mathrm{Ac}$ & $05.36 \mathrm{Bd}$ & $02.18 \mathrm{Bd}$ & $0.18 \mathrm{Bd}$ \\
Hemopexin & & & & & & & & \\
G1 & $35.31 \mathrm{Aa}$ & $60.86 \mathrm{Cb}$ & $103.49 \mathrm{Cc}$ & $72.99 \mathrm{Bb}$ & $65.98 \mathrm{Bb}$ & $49.98 \mathrm{Cb}$ & $33.70 \mathrm{Ab}$ & $20.61 \mathrm{Ab}$ \\
G2 & $32.89 \mathrm{Aa}$ & $46.24 \mathrm{Bb}$ & $46.09 \mathrm{Ab}$ & $38.27 \mathrm{Aa}$ & $23.98 \mathrm{Aa}$ & $21.13 \mathrm{Aa}$ & $05.50 \mathrm{Bc}$ & $04.49 \mathrm{Bc}$ \\
Haptoglobin & & & & & & & & \\
G1 & $28.2 \mathrm{Aa}$ & $82.0 \mathrm{Cb}$ & $117.31 \mathrm{Cc}$ & $103.80 \mathrm{Cc}$ & $88.23 \mathrm{Bb}$ & $87.40 \mathrm{Cb}$ & $85.82 \mathrm{Ab}$ & $19.44 \mathrm{Aa}$ \\
G2 & $12.1 \mathrm{Aa}$ & $14.92 \mathrm{Bb}$ & $79.77 \mathrm{Ac}$ & $92.80 \mathrm{Cc}$ & $59.35 \mathrm{Bc}$ & $58.42 \mathrm{Cc}$ & $53.99 \mathrm{Ac}$ & $44.25 \mathrm{Cc}$ \\
Acid glicop & & & & & & & & \\
G1 & $28.35 \mathrm{Aa}$ & $41.60 \mathrm{Bb}$ & $199.06 \mathrm{Cc}$ & $138.64 \mathrm{Cc}$ & $85.06 \mathrm{Bc}$ & $58.55 \mathrm{Cb}$ & $34.99 \mathrm{Aa}$ & $19.44 \mathrm{Aa}$ \\
G2 & $12.86 \mathrm{Ba}$ & $13.56 \mathrm{Db}$ & $74.56 \mathrm{Ac}$ & $73.89 \mathrm{Bb}$ & $68.67 \mathrm{Bb}$ & $54.74 \mathrm{Cb}$ & $53.05 \mathrm{Ab}$ & $45.18 \mathrm{Cd}$ \\
\hline
\end{tabular}

Means followed by distinct capital letters in columns and lower case letters in rows are different $(\mathrm{P}<0.05)$.

The results showed that the pattern of increase and decrease of acute phase proteins, as well as that of neutrophils, may be useful in the evaluation of inflammatory response induced by surgical procedures.

Moreover, it is possible that the analysis of these parameters in the postoperative period may be useful in the detection of undesirable alterations, such as inflammation/infection and, consequently, in defining a prognosis. It is also possible that the intensity of inflammatory response due to any conventional surgery and also by laparoscopy may be evaluated by means of acute phase protein determination and the leukogram.

\section{CONCLUSION}

The results confirm that SDS-PAGE technique and leukogram are diagnostic tools, able to show the intensity of inflammatory answer after conventional and laparoscopic ovariectomy in queens. The postoperative period of ovariectomy procedure in queens by laparoscopy showed lower serum acute phase protein levels, and seems to induce low inflammatory answer, in comparison to conventional procedure.

\section{REFERENCES}

BONICA, J.J. Pain research and therapy history, current status and future goals. In: SHORT, C.E.; POZNACK, A.V. (Ed.). Animal pain. New York: Churchil Livingston, 1992. p.1-29.

BRUN, M.V. Ovário-histerectomia em caninos por cirurgia laparoscópica. 1999. 181f. Dissertação (Mestrado) - Faculdade de Veterinária, Universidade Federal do Rio Grande do Sul, Porto Alegre.

BUSH, B.M. White blood cells (WBCs). In: Interpretation of laboratory results for small animal clinicians. Oxford: Blacwell Scientific, 1991. p.132-195.

FAGLIARI, J.J.; FERREIRA NETO, J.M.; LUCAS, A. Proteinograma total e fracionamento eletroforético do soro de bezerros Guzerá passivamente imunizados contra paratifo. Arq. Bras. Med. Vet. Zootec., v.35, p.317-332, 1983.

FAGLIARI, J.J.; McCLENAHAN, D.; EVANSON, O.A. Changes in plasma proteína concentrations in ponies with experimentally induced alimentary laminits. Am. J. Vet. Res., v.59, p.1234-1237, 1997. 
FAGLIARI, J.J.; SILVA, S.L. Hemograma e proteinograma plasmático de equinos hígidos e de equinos acometidos por abdômen agudo, antes e após laparotomia. Arq. Bras. Med. Vet. Zootec., v.54, p.559-567, 2002.

GRUYS, E.; OBWOLO, M.J.; TOUSSAINT, M.J.M. Diagnostic significance of the major acute phase proteins in veterinary clinical chemistry: a review. Vet. Bull., v.64, p.10091018, 1994.

HEINDRICH, P.C.; CASTELL, J.V.; ANDUS, T. Interleukin-6 and acute phase response. Biochem. J., v.256, p.621-636, 1990.

JAIN, N.C. The erythrocyte in disease. In:

Schalm's veterinary hematology. 3.ed. Philadelphia: Lea \& Febiger, 1986. p.405-470.

KANEKO, J.J. Clinical biochemistry of domestic animals. 6.ed. San Diego: Academic, 2008. $916 \mathrm{p}$.

KENT, J. Acute phase proteins: their use in veterinary diagnosis. Br. Vet. J., v.148, p.279$282,1992$.

MALM, C.; SAVASSI-ROCHA, P.R.; GHELLER, V.A. et al. Ovário-histerectomia: estudo experimental comparativo entre as abordagens laparoscópica e aberta na espécie canina. II Evolução clínica pós-operatória. Arq. Bras. Med. Vet. Zootec., v.57, supl.2, p.162-172, 2005.
MATTEWS, A.G. Serum protein electrophoresis in horses and ponies. Equine Vet. J., v.14, p.322324, 1982.

MURATA, H.; SHIMADA, N.; YOSHIOKA, $M$. Current research on acute phase proteins in veterinary diagnosis: an overview. Vet. J., v.168, p.28-40, 2004.

OKKENS, A.C.; KOOISTRA, H.S.; NEICKEL, R.F. Comparison of long-term effects of ovariectomy versus ovariohisterectomy in bitches. J. Reprod. Fertil., v.51, suppl., p.227231, 1997.

PALTRINIERI, S. The feline acute phase reaction. Vet. J., v.177, p. 26-35, 2008.

PETERSEN, H.H.; NIELSEN, J.P.; HEEGAARD, P.M.H. Application of acute phase protein measurements in veterinary clinical chemistry. Vet. Res., v.35, p.163-187, 2004.

TVEDTEN, H. Leucocytes disorders. In: WILLIARD, M.D.; TVEDTEN, H.; TURNWALD, G.H. Small animal clinical diagnosis by laboratory methods. 2.ed. Philadelphia: W.B. Saunders, 1994. p.53-79.

WEBER, K.; OSBORN, M. The reliability of molecular weight determinations by dodecyl sulfate-polyacrylamide gel electrophoresis. $J$. Biol. Chem., v.244, p.4406-4412, 1969. 